Columbia Law School

Scholarship Archive

1994

\title{
Four Reasons and a Paradox: The Manifest Superiority of Copyright over Sui Generis Protection of Computer Software
}

Jane C. Ginsburg

Columbia Law School, jane.ginsburg@law.columbia.edu

Follow this and additional works at: https://scholarship.law.columbia.edu/faculty_scholarship

Part of the Computer Law Commons, and the Intellectual Property Law Commons

\section{Recommended Citation}

Jane C. Ginsburg, Four Reasons and a Paradox: The Manifest Superiority of Copyright over Sui Generis Protection of Computer Software, 94 CoLuM. L. Rev 2559 (1994).

Available at: https://scholarship.law.columbia.edu/faculty_scholarship/61

This Article is brought to you for free and open access by the Faculty Publications at Scholarship Archive. It has been accepted for inclusion in Faculty Scholarship by an authorized administrator of Scholarship Archive. For more information, please contact scholarshiparchive@law.columbia.edu. 


\title{
SYMPOSIUM COMMENTS
}

\author{
FOUR REASONS AND A PARADOX: THE MANIFEST \\ SUPERIORITY OF COPYRIGHT OVER SUI GENERIS \\ PROTEGTION OF COMPUTER SOFTWARE
}

\author{
Jane C. Ginsburg*
}

The "Manifesto Concerning the Legal Protection of Computer Programs"1 offers an extensive and challenging critique of current intellectual property protection of software. The authors argue strongly that the law should focus on the value of the know-how embodied in programs and the importance of protecting it, rather than on the particular means which might be used to appropriate it. ${ }^{2}$ The authors seek to compel reconceptualization of the place of computer programs, and of software authors' creativity, within the domain of intellectual property. However, their brief for change manifests several flaws. Paradoxically, it comes at once both too soon and too late. In addition, its expectation for the adoption of its proposed alternatives is too optimistic, while its perception of the ability of copyright law to afford appropriate protection for computer programs is too pessimistic.

The Manifesto's objectives and the moment chosen for their declaration are perplexing, if not quixotic. As the authors on several occasions acknowledge, ${ }^{3}$ the computer software industry is currently thriving. Moreover, copyright protection for computer programs has now become the worldwide norm. Not only the U.S., but the E.C. and all members of the General Agreement on Tariffs and Trade have determined to protect computer programs as literary works, within the meaning of the dominant international copyright convention. ${ }^{4}$ Even supposing that a specter of over- and underprotection haunts the software industry, the alternative intellectual property regimes the authors evoke are likely neither to achieve domestic enactment, nor to secure broad and effective international agreement. Finally, the Manifesto's essential premise, that copyright law ill befits computer programs because the law does not protect works that "behave," betrays too cramped an appreciation of the subject matter and scope of copyright protection. Copyright does, to some ex-

* Morton L. Janklow Professor of Literary and Artistic Property Law, Columbia University School of Law.

1. Pamela Samuelson, et al., A Manifesto Concerning the Legal Protection of Computer Programs, 94 Colum. L. Rev. 2308 (1994) [hereinafter Manifesto].

2. See id. at 2333-42.

3. See id. at 2376, 2378.

4. Agreement on Trade-Related Aspects of Intellectual Property Rights, Including Trade in Counterfeit Goods, Dec. 15, 1993, art. 10, 33 I.L.M. 83, 87 (1994) [hereinafter GATT/TRIPs]. 
tent, protect "behavior," whether of computer programs or of other works of authorship. The primary problem is to delineate how much "behavior" copyright will cover; but that problem haunts all of copyright. If the specter the Manifesto summons is not entirely spurious, neither is it purely computer-specific.

\section{The Manifesto's Timing: Too Soon to Tell AND TOO LATE TO SWITCH}

\section{A. Too Soon}

The authors proffer no evidence that copyright protection of computer programs is currently chilling software development. On the contrary, the Manifesto recognizes the industry's continued vitality. However, posit the authors, recent restrictive trends in the courts, as well as anticipated technological developments in reverse engineering, portend ill for future program innovation. ${ }^{5}$ Both these propositions are problematic. First, if the judicial pendulum seemed at first to swing toward sweeping protection of even the most abstract elements of computer programs, ${ }^{6}$ and then toward stingy protection of only the program's literal text, ${ }^{7}$ courts now appear to be drawing a more moderate arc. For example, all Circuits that have addressed the question agree that, in principle, copyright protects not only literal code, but also nonliteral elements of a program, such as its structure, sequence and organization. ${ }^{8}$ Courts disagree over the level of abstraction at which the program will be protected, as well as over the identification of the "expression" that may be protected without risk of monopolizing the "idea" or "process" underlying the program. ${ }^{9}$ But this disagreement is hardly peculiar to computer programs. It exists in judicial analyses, for example, of nonfiction literary works, ${ }^{10}$

5. See, e.g., Manifesto, supra note 1, at 2341-42, 2357-61.

6. See, e.g., Whelan Assocs. v. Jaslow Dental Lab., Inc., 797 F.2d 1222 (3d Cir. 1986), cert. denied, 479 U.S. 1031 (1987).

7. See, e.g., Computer Assocs. Int'l v. Altai, Inc., 982 F.2d 693 (2d Cir. 1992); Apple Computer, Inc. v. Microsoft Corp., 799 F. Supp. 1006 (N.D. Cal. 1992), aff'd, 35 F.3d 1435 (9th Cir. 1994).

8. See, e.g., Engineering Dynamics Inc. v. Structural Software, Inc., 26 F.3d 1335, 1342-46 (5th Cir. 1994); Gates Rubber Co. v. Bando Chem. Indus., 9 F.3d 823 (10th Cir. 1993); Altai, 982 F.2d at 701, 706-10; Whelan, 797 F.2d at 1237-40, 1242-43.

9. Compare Plains Cotton Coop. Assoc. v. Goodpasture Computer Serv., Inc., 807 F.2d 1256, 1262 (5th Cir. 1986) (structure of cotton commodities sales program held necessary to the idea of such a program) with Whelan, 797 F.2d at 1237-40 ("structure, sequence and organization" of program for business management of a dental laboratory held protectable "expression").

10. Compare Wainwright Sec. v. Wall Street Transcript Corp., 558 F.2d 91, 96 (2d Cir. 1977), cert. denied, 434 U.S. 1014 (1978) (" $[T]$ he essence of infringement lies not in taking a general theme or in coverage of the reports as events, but in appropriating the 'particular expression through similarities of treatment, details, scenes, events and characterization.' ") with Hoehling v. Universal City Studios, 618 F.2d 972 (2d Cir.), cert. denied, 449 U.S. 841 (1980) (holding that interpretations of historical events are not copyrightable as a matter of law). 
and of plays." As Learned Hand warned, "Nobody has ever been able to fix that boundary [between 'ideas' and 'expression'] and nobody ever can." 12

There is a danger, but not only with respect to computer programs, that courts, in seeking to distinguish the public domain "idea" from the protected "expression," will so "dissect" the work as to classify all its elements as unprotectable. Indeed, the Second Circuit did so flay the expression of a computer program operating system in Computer Associates $v$. Altai $^{13}$ But other courts, including those deciding cases concerning computer programs, have recognized that zeal to eliminate unprotectable elements may blind the court to the expressiveness of their ensemble. ${ }^{14}$ Thus the Tenth Circuit, while endorsing the "abstraction-filtration-comparison" test announced in Altai, added this important gloss:

We suggest that a court will often be assisted in determining the factual issue of copying if both programs are first compared in their entirety without filtering out the unprotected elements. ... [A] $\mathrm{n}$ initial holistic comparison may reveal a pattern of copying that is not obvious when only certain components are examined. ${ }^{15}$

The Fifth Circuit has followed the Tenth in effecting an overall comparison of the works at issue: "The ultimate focus ... should be on the input formats and output reports taken as a whole."16 If courts continue to keep sight of the work as a whole, the fear of underprotection may dissipate.

Second, and especially poignant in light of the judicial developments just evoked, it is hazardous to devise a new "market-oriented" intellectual property regime to respond to conditions yet to be created. The "market" foreseen by the lawmaker today may be quite different from the market that actually appears tomorrow. ${ }^{17}$ The "orientation" sought might

11. Compare Nichols v. Universal Pictures Corp., 45 F.2d 119 (2d Cir. 1930), cert. denied, 282 U.S. 902 (1931) (general plots and story patterns are in the public domain) with Sheldon v. Metro-Goldwyn Pictures Corp., 81 F.2d 49 (2d Cir. 1936) (finding the defendant's film infringed copyright because it drew on more than just general patterns of earlier work, and borrowed its expression).

12. Nichols, $45 \mathrm{~F} .2 \mathrm{~d}$ at 121.

13. 982 F.2d 693 (2d Cir. 1992). The Second Circuit has applied the same technique to disqualify much of a historical novel from copyright protection. See Hoehling, 618 F.2d at $974-80$.

14. This is particularly true when the creativity lies in the arrangement of the work's components rather than their content. This problem also exists in the context of more traditional works of authorship. See, e.g., Warner Bros. v. American Broadcasting Cos., 720 F.2d 231, 242-43 (2d Cir. 1983) (comparing the total perception of a new television superhero and Superman).

15. Gates Rubber Co. v. Bando Chemical Indus., 9 F.3d 823, 841 (10th Cir. 1993).

16. Engineering Dynamics, Inc. v. Structural Software, Inc., 26 F.3d 1335, 1348 (5th Cir. 1994).

17. Cf. 17 U.S.C. $\$ 111$ (1988) (extensive and detailed disposition concerning compulsory licensing of television programs for cable distribution). Many of the economic assumptions underlying the drafting of this provision in the mid-1970s were already out-of- 
then prove to have gone astray. Moreover, as Part II will develop, it may well be more difficult to enact a "market-oriented" noncopyright regime in the U.S., than to continue the work of judicial adaptation of copyright principles to software. As a general proposition, courts and copyright counselors may be more at ease applying known principles and analyses to new subject matter, than interpreting a new text that purports to present a new and particular approach. ${ }^{18}$

\section{B. Too Late}

Copyright protection of computer programs is not simply compatible with software creators' needs; it has become the international intellectual property norm. Since the U.S. confirmed the copyrightability of computer programs in 1980, ${ }^{19}$ many Western European countries have amended their copyright laws to provide explicitly for computer program protection. ${ }^{20}$ This process in Western Europe culminated in the adoption of the 1991 European Community Directive on the Legal Protection of Computer Programs. ${ }^{21}$ Most significantly, as of April 1994, the 105 members of the General Agreement on Tariffs and Trade (GATT) have committed, as a matter of international trade policy, to the protection of computer programs by copyright law. Under article 10 of the Agreement

date by the time the law became effective in 1978. See, e.g., Stanley M. Besen et al., Copyright Liability for Cable Television: Compulsory Licensing and the Coase Theorem, 21 J.L. \& Econ. 67 (1978); see also Nathan Rosenberg, Exploring the Black Box (1994) (discussing difficulty of forecasting exploitations of new technologies). Professor Kenneth W. Dam has criticized proposals for sui generis protection of software for similar reasons. Looking to the experience under the 1984 Semiconductor Chip Protection Act, Prof. Dam argues that "technology outpaced the Congress. ... '[S]ome of the basic definitions [of the Act] are already obsolete, leaving important parts of mask works technology outside the protection of that legislation.' ... [T] he usefulness of sui generis legislation in an industry characterized by rapid technological change is called into question by the experience under the 1984 Act." Kenneth W. Dam, Some Economic Considerations in the Intellectual Property Protection of Software 67 (Chicago Law \& Economics Working Paper No. 26, 2d series 1994).

18. See Leo J. Raskind, The Uncertain Case for Special Legislation Protecting Computer Software, 47 U. Pitt. L. Rev. 1131 (1986).

19. See Act of December 12, 1980, Pub. L. No. 96-517, ch. 38, sec. 211, 94 Stat. 3015, 3028 (codified as amended at 17 U.S.C. $\$ \S 101,117$ (1988)) (adding a definition of computer program to $\S 101$ of the 1976 Copyright Act, and a new $\S 117$ on the rights of owners of copies of computer programs).

20. See, e.g., Copyright Statute, J.O., No. 85-660, July 4, 1985 (France); Administration of Copyright BGBI, No. 58, 1985 (Germany); Copyright Statute, B.O.E., No. 27, Nov. 17, 1987 (Spain).

21. See Council Directive $91 / 250$ of 14 May 1991, 1991 O.J. (L 122) 42. For commentary on the E.C. software directive, see, e.g., Thomas Dreier, The Council Directive of 14 May 1991 on the Legal Protection of Computer Programs, 13 Eur. Intell. Prop. Rev. 319 (1991); Jérōme Huet \& Jane C. Ginsburg, Computer Programs in Europe: A Comparative Analysis of the 1991 EC Software Directive, 30 Colum. J. Transnat'l L. 327 (1992); Alan K. Palmer \& Thomas C. Vinje, The EC Directive on the Legal Protection of Computer Software: New Law Governing Software Development, 2 Duke J. Comp. \& Int'1 L. 65 (1992). 
on Trade-Related Aspects of Intellectual Property (TRIPs), ${ }^{22}$ GATT members recognize that computer programs are literary works within the meaning of the Berne Convention (the leading multilateral copyright treaty), and undertake to protect them accordingly. The GATT/TRIPs accord was reached following years of intense multilateral negotiations; ${ }^{23}$ it seems most unlikely that, having at last secured agreement on copyright as the international norm, GATT members will soon substitute a different protective regime.

Moreover, there is no ready alternative to copyright as provided in GATT/TRIPs. The Manifesto optimistically suggests that article 10bis of the Paris Convention for the Protection of Industrial Property could provide effective international protection against "cloning." ${ }^{24}$ This is doubtful. To be sure, article 10bis includes a general obligation to member countries "to assure to nationals of ... [Union] countries effective protection against unfair competition." 25 However, this provision has not afforded a meaningful guarantee, for the treaty's definition of unfair competition leaves too much room for inconsistent and uncertain application.

The text prohibits "[a]ny act of competition contrary to honest practices in industrial or commercial matters." 26 The two key terms are "act of competition" and "contrary to honest practices." These terms, however, refer to different legal regimes. According to a leading commentary on the treaty, the national law of each member country will determine what acts constitute "acts of competition," while international trade norms will determine the meaning of "honest practices."27

22. GATT/TRIPs, supra note 4, 33 I.L.M. at 87.

23. On the issues and process leading to adoption of GATT/TRIPs, see, e.g., Marshall A. Leaffer, Protecting United States Intellectual Property Abroad: Toward a New Multilateralism, 76 Iowa L. Rev. 273, 303 (1991); Emery Simon, U.S. Trade Policy and Intellectual Property Rights, 50 Alb. L. Rev. 501, 505-06 (1986); Jacques J. Gorlin, GATT: A View from the United States, 5 Canadian Intell. Prop. L. Rev. 275 (1989); J.H. Reichman, Intellectual Property in International Trade: Opportunities and Risks of a GATT Connection, 22 Vand. J. Transnat'1 L. 747, 883-86 (1989); Liberalization of Services and Intellectual Property in the Uruguay Round of GATT (Giorgio Sacerdoti ed., 1990).

24. See Manifesto, supra note 1, at 2424.

25. Paris Convention for the Protection of Industrial Property, art. 10bis(1), March 20, 1883, as revised at Stockholm on July 14, 1967, 21 U.S.T. 1583, 1648, 828 U.N.T.S. 305, 337 [hereinafter Paris Convention].

26. Id., art. 10 bis(2), 21 U.S.T. at 1648, 828 U.N.T.S. at 337.

27. G.H.C. Bodenhausen, Guide to the Application of the Paris Convention for the Protection of Industrial Property 144 (1968). The Guide enjoys a high degree of authority, as it was written by the Director of the United International Bureau for the Protection of Intellectual Property (BIRPI), the predecessor organization to World Intellectual Property Organization (WIPO), the entity charged with administering the Paris and Berne Conventions.

As an example of international trade norms, the recent GATT/TRIPs accord incorporates Paris Convention art. 10bis with respect to protection of trade secrets, and defines "a manner contrary to honest commercial practices" as "at least practices such as breach of contract, breach of confidence and inducement to breach, and includes the 
The treaty's failure to give content to these terms seriously weakens article 10bis. Consider the unauthorized adaptation of a computer program to a "hardware platform" for which it was not originally designed. Reference to a given member country's law may yield different responses as to whether the unauthorized transporting of the program would constitute "competition." ${ }^{28}$ If it would not, then even if the conduct complained of were "contrary to honest practices," the treaty apparently would not apply. For example, assume that breaking into computer security codes or tapping into telephone connections violates international norms of "honest practices." ${ }^{29}$ Assume also that, in the applicable forum, using the information thus acquired to create a related, but not directly competing program is not an act of "competition." In that case, the Paris Convention may not require awarding relief.

Similarly, even if the forum would classify the challenged act as "competition," if the act does not also violate international norms of "honest practices," then article 10bis will not apply. Thus, if defendant "clones" a user interface, but does so using publicly available information, it is not clear that (in the absence of copyright protection) this act would violate international standards of fair play. As a result, one must question the ability of the Paris Convention to supply an alternative norm of intellectual property protection for computer programs.

These pragmatic concerns about the timing of the Manifesto might yield to a demonstration that, as a matter both of practice and of principle, a sui generis software protection regime would provide better, surer, and more harmonious coverage for creativity in programming. In fact, however, as Part II maintains, in the U.S. there is little security to be gained from abandoning copyright in favor of unfair competition law. Moreover, copyright protection of computer programs is not as discordant as the Manifesto contends.

acquisition of undisclosed information by third parties who knew, or were grossly negligent in failing to know, that such practices were involved in the acquisition." GATT/TRIPs, supra note 4, art. 39.1, 39.2 n.10, 33 I.L.M. at 98.

28. Cf. Judgment of Feb. 12, 1989 (Veuve Clicquot-Ponsardin v. Franco Zari Profumerie), Cass. LX Il Diritto di Autore 419 (Italy) (since champagne and bubble bath are directed at different markets, no unfair competition found when Italian producer of bubble bath packaged his product in a bottle labelled with the champagne mark Veuve Clicquot).

29. Cf., Jean-Luc Crozafon, La question toujours en suspens du régime juridique des écoutes têléphoniques [The Unresolved Status of the Legal Regime for Wire Tapping], 1989 Droit de l'informatique et des télécoms 27, 30 (telephone tapping as a form of unfair competition). 
II. Choice of Intellectual Property Regime: Too Optimistic About Alternatives and Too Pessimistic About Copyright

\section{A. Too Optimistic}

The bulk of the Manifesto addresses the perceived inadequacies or inappropriateness of traditional forms of intellectual property law to regulate computer programs. The authors' treatment of alternatives is, however, regrettably scant. In essence, the authors propose to substitute either a "registration system for innovative compilations of applied knowhow embodied in software,"30 or a misappropriation-based regime of unfair competition law. ${ }^{31}$ Neither alternative seems likely to succeed, at least not imminently.

With respect to the registration alternative, so long as effective copyright or trade secret protections are available, software proprietors are unlikely to be willing to trade them for a compulsory license registration system. This is because the proposed registry, while affording compensation, denies the registrants any control over the use of their works. Collective or compulsory licensing substitutes compensation for control where there is no effective means to police unauthorized exploitation, or where the transaction costs of negotiated licenses are too high. ${ }^{32}$ It is therefore not a first resort. ${ }^{33}$ The envisioned registry could have considerable appeal as a voluntary adjunct to copyright protection (particularly if its details were more developed than they are in the Manifesto), and some software producers may well find it highly desirable some of the time. But absent a genuine crisis in the traditional intellectual property protection of computer programs, a generalized and exclusive registration/compulsory license system seems a remote possibility.

The Manifesto's proposal to substitute unfair competition law for property-right based regimes ignores the persistent opposition by the Supreme Court and other persuasive authority to the resurrection of common-law misappropriation claims. For example, the American Law Institute, in the recently issued Restatement of the Law of Unfair Competition, has rejected the misappropriation doctrine, stressing that no liability exists for the mere appropriation of "intangible trade values." 34 The

30. Manifesto, supra note 1 , at 2426 .

31. See id. at 2423.

32. See, e.g., Robert Cassler, Copyright Compulsory Licenses-Are They Coming or Going?, 37 J. Copyright Soc'y 231 (1990); Paul Goldstein, Preempted State Doctrines, Involuntary Transfers and Compulsory Licenses: Testing the Limits of Copyright, 24 UCLA L. Rev. 1107, 1137-38 (1977).

33. See, e.g., Besen et al., supra note 17, at 76-85 (economists' critique of compulsory licensing in copyright).

34. Restatement of the Law of Unfair Competition $\S 38$ (Tentative Draft No. 4, 1993).

The drafters of the Restatement explained the purpose of Section 38 as follows:

Section 38 rejects a more general claim against misappropriation sometimes said to derive from International News Service v. Associated Press . . . . We conclude that the Supreme Court's decision in the INS case has not been widely incorporated into the common law of the states, that its force is limited by its unusual facts, and 
intellectual property decisions of the Supreme Court buttress the Restatement. For example, in Bonito Boats $v$. Thunder Craft Boats, ${ }^{35}$ the Court ruled that a Florida "plug-molding" statute (providing, in effect, "anticloning" protection for boat hulls) was preempted by federal patent law. The Court's rationale extends beyond federalism concerns, for the Court stressed the general principle of free copying: "free exploitation of ideas will be the rule, to which the protection of a federal patent is the exception .... [T] tected, but also what is free for all to use." 36 In other words, if the innovation is not protected by a formal property-right regime, then neither federal nor state courts should entertain interstitial anti-copying claims.

Of course, Congress could enact a Federal Unfair Competition Act pursuant to the Commerce Clause, ${ }^{37}$ but the content of such a law requires careful consideration. Unfortunately, the Manifesto gives too little attention to the detail of legislative approaches.

\section{B. Too Pessimistic}

The Manifesto's central criticism of copyright protection for computer programs emphasizes that software "behaves," and that copyright does not protect "behavior," particularly if the "behavior" is "functional." 38 There are at least two difficulties with this contention. First, copyright in fact protects a wide variety of works that "behave." Second, "functionality" is not a general bar to copyright protection. Traditionally, copyright subsists in original works of authorship whatever the purpose of the work, ${ }^{39}$ so long as a multitude of means of achieving the "purpose" remain available. The problem is defining the "purpose" in a way that promotes the creativity not only of the first-comer, but also of subsequent authors in the same field.

that developments in the law of federal preemption limit its potential application.

Accordingly, we conclude that the decision should not be restated as a rule of general applicability.

Id. $\S 38$ Reporters' Memorandum (citation omitted).

35. 489 U.S. 141 (1989).

36. Id. at 151 (1989); see also Sears Roebuck \& Co. v. Stiffel Co., 376 U.S. 225, 232-33 (1964) (holding that the lower court erred in affording protection to an unpatented and uncopyrighted pole lamp); Compco Corp. v. Day-Brite Lighting, Inc., 376 U.S. 234 (1964) (rejecting state anticopying protection for unpatented lamp designs).

37. On Congress's power to enact noncopyright or nonpatent intellectual property regimes, see, e.g., Jane C. Ginsburg, No "Sweat"? Copyright and Other Protection of Works of Information after Feist v. Rural Telephone, 92 Colum. L. Rev. 338, 367-87 (1992). See also Pamela Samuelson, Creating a New Kind of Intellectual Property: Applying the Lessons of the Chip Law to Computer Programs, 70 Minn. L. Rev. 471, 519-20 (1985).

38. See, e.g., Manifesto, supra note 1 at 2347-56.

39. Pictorial, graphic, and sculptural works are an exception to this principle. See 17 U.S.C. $\$ 101$ (1988). The Manifesto's authors have generalized the "useful article" limitation on these works to copyrighted works as a whole. See infra notes 52-53. 
Copyrighted works that "behave" include architectural plans, ${ }^{40}$ choreography, ${ }^{41}$ musical scores, ${ }^{42}$ musical editions, ${ }^{43}$ and stage direction. ${ }^{44}$ All these works set forth ways of achieving "a certain result." 45 Moreover, these works share the duality of "text" and "behavior" described by the Manifesto. ${ }^{46}$ For example, the "text" of a musical score or of a choreographic work exists to be executed; the notations have value primarily as instructions to the performance of the musical or choreographic task. As with computer programs, the particular form of the "instructions" does not define the work: if a choreographic work is initially expressed in Laban notation, it is no excuse to an infringement charge that defendant's copy was rendered in Benesh notation. The "work" is the collection of dance movements, not the particular language in which the movement is expressed. By the same token, the code in which a computer program is written sets forth, but does not necessarily constitute, the copyrighted work.

One might object that this discussion has so far concerned aesthetic works, while computer programs are "functional." But copyright also protects architectural plans, even though these set forth instructions to construct a "functional" object, a building. Moreover, since the $1990 \mathrm{Ar}$ chitectural Works Copyright Protection Act, ${ }^{47}$ it is clear that architectural plans are infringed not only by copying in the initial format, but also by following the plans to execute the building, ${ }^{48}$ so long as the building's function does not compel its form. ${ }^{49}$

In general, apart from the specific category of "pictorial, graphic and sculptural works," U.S. copyright law does not distinguish between "aesthetic" and "functional" works. Congress has attempted to divide the useful from the beautiful with respect to artworks by requiring that artistic elements of "useful articles" be separable from the article's utilitarian aspects. ${ }^{50}$ However, the artworks regime is both anomalous and largely un-

40. See 17 U.S.C. $\S \S 101,102(a)(8)$ (1988 \& Supp. V 1993).

41. See id. $\$ 102(a)(4)$.

42. See id. $\$ 102(a)(2)$.

43. See id. $\S \S 101,103$, which protects derivative works. Editions are considered "derivative works." See, e.g., 1 Paul Goldstein, Copyright: Principles, Law and Practice $\S 1.6 .2$, at 32 (1989).

44. See Jessica Litman, Copyright in the Stage Direction of a Broadway Musical, 7 Colum.-VLA J.L. \& Arts 309, 312-18 (1983).

45. Cf. 17 U.S.C. $\$ 101$ (1988) (definition of a computer program).

46. See Manifesto, supra note 1 , at 2316.

47. Pub. L. No. 101-650, Title VI, 104 Stat. 5089 (1990).

- 48. See, e.g., H.R. Rep. No. 735, 101st Cong., 2d Sess. at 19 (1990); Jane C. Ginsburg, Copyright in the 101st Congress: Commentary of the Visual Artists Rights Act and the Architectural Works Copyright Protection Act of 1990, 14 Colum.-VL.A J.L. \& Arts 477, 492-93 \& $\mathrm{n} .61$ (1990). The building itself must satisfy minimum standards of originality, see 17 U.S.C. $\S 101$ (1988) (definition of an "architectural work").

49. See H.R. Rep. No. 735, supra note 48 , at $20-21$.

50. See 17 U.S.C. $§ 101$ (1988) (definitions of "useful article" and "pictorial, graphic and sculptural works"). 
satisfactory in application. ${ }^{51}$ It would be both inaccurate and unfortunate to extrapolate from the peculiar regulation of applied art a rule of general applicability to "useful" works of authorship. ${ }^{52}$ No general copyright doctrine of "applied literature" 53 exists. ${ }^{54}$

Instead, copyright law in general addresses the kind of concerns that underlie the applied art limitation-fear of monopolization of inappropriate subject matter-through the long-established idea-expression dichotomy and idea-expression merger doctrines. The copyright statute, adopting a long case-law tradition, ${ }^{55}$ codifies the idea-expression dichotomy as follows: "In no case does copyright protection for an original work of authorship extend to any idea, procedure, process, system, method of operation ... regardless of the form in which it is . . embodied in such work." 56 In other words, while the overall presentation of a work exposing ideas or describing a process is protected, the ideas disclosed or processes revealed are not. The merger doctrine, as applied in myriad judicial decisions, denies copyright protection to those expressions of ideas that permit too few variations, lest by protecting the expression copyright also privatize the idea. ${ }^{57}$ Hence, it is not surprising that in many of the computer software litigations, courts have rejected merger

51. See, e.g., Shira Perlmutter, Conceptual Separability and Copyright in the Designs of Useful Articles, 37 J. Copyright Soc'y 339 (1990) (detailed discussion of the case law).

52. See Manifesto, supra note 1 , at 2352 , in which the authors evoke the pictorialgraphic-sculptural work "useful article" doctrine, and recommend its extension to distinguishing functional from expressive behaviors.

However, the extension is imperfect, since the statute excludes from the realm of "useful articles" works "having an intrinsic utilitarian function . . . merely to . . . convey information." 17 U.S.C. $\$ 101$ (1988). And the Manifesto authors undercut the useful article analogy with their own earlier characterization of computer programs as information products constructed from information components. See Manifesto, supra note 1, at 2335-36, 2367.

53. The term comes from the work of Professor Jerome Reichman, who has long argued for an extension of the applied art regime to utilitarian literature. See, e.g., Jerome H. Reichman, Computer Programs as Applied Scientific Know-How: Implications of Copyright Protection for Commercialized University Research, 42 Vand. L. Rev. 639 (1989).

54. See also Dam, supra note 17, at 3-7 (rejecting functionality objection to copyright protection for software, and concluding that "the usefulness of software is an argument for, rather than against, copyright protection for software.").

55. See, e.g., Baker v. Selden, 101 U.S. 99 (1879) (rejecting attempt to invoke copyright protection of accounting forms in order to prevent unauthorized use of the bookkeeping system).

56. 17 U.S.C. § 102(b) (1988).

57. See, e.g., Herbert Rosenthal Jewelry Corp. v. Kalpakian, 446 F.2d 738, 742 (9th Cir. 1971) (arrangement of jewels on bee-shaped pins); Morrissey v. Procter \& Gamble Co., 379 F.2d 675, 678-79 (1st Cir. 1967) (soapbox sweepstakes contest rules); Continental Casualty Co. v. Beardsley, 253 F.2d 702, 706 (2d Cir.), cert. denied, 358 U.S. 816 (1958) (insurance forms). Moreover, the "merger" doctrine applies to all works, whether useful or frivolous. The idea-expression dichotomy is codified at 17 U.S.C. $\$ 102$ (b) (1988). 
defenses when a plaintiff shows that unrelated competitors are exploiting functionally similar programs that were not copied from the plaintiff's. ${ }^{58}$

However, evocation of the idea-expression dichotomy and merger doctrines does not resolve the problem, without also elucidating what constitutes an unprotectable idea, and what comprises protectable expression. This is one of the hardest tasks in traditional copyright analysis. ${ }^{59}$ It remains difficult, but not necessarily more so, when computer programs are at issue.

Congress has supplied two arguably inconsistent directives pertinent to computer programs. First, for all works of authorship, Congress in the 1976 Copyright Act declared that protection does not "extend to . . . process[es]."60 Second, in 1980, Congress enacted amendments to the 1976 Act, to make clear that computer programs are protected by copyright law. Congress then defined a "computer program" as "a set of statements or instructions to be used directly or indirectly in a computer in order to bring about a certain result." 61 There may be some tension between

58. See, e.g., Engineering Dynamics, Inc. v. Structural Software, Inc., 26 F.3d 1335, 1344-45 (5th Gir. 1994) (rival offshore oil platform engineering programs); Whelan Assocs. v. Jaslow Dental Lab., Inc., 797 F.2d 1222, 1238-39 (3rd Cir. 1986), cert. denied, 479 U.S. 1031 (1987) (rival dental lab management programs); Lotus Dev. Corp. v. Paperback Software Int'l, 740 F. Supp. 37, 65-66 (D. Mass. 1990) (rival spreadsheet programs). By contrast, in Plains Cotton Coop. Assoc. v. Goodpasture Computer Serv., Inc., 807 F.2d 1256, 1260-61 (5th Cir. 1987) no evidence was submitted of rival cotton market programs that had not been copied from the plaintiff's; the Court found a merger of the program's idea and the expression of the program's nonliteral structure. In this respect, one might observe that the courts' analyses have been "market oriented." Cf. Manifesto, supra note 1, at 2365-66 (proposing a market oriented approach to protect against "trivial acquisitions of equivalence [that would have] market destructive effects").

59. See, e.g., Peter Pan Fabrics, Inc. v. Martin Weiner Corp., 274 F.2d 487, 489 (2d Cir. 1960) (L. Hand, J.) ("[N]o principle can be stated as to when an imitator has gone beyond copying the 'idea,' and has borrowed its 'expression.' Decisions must therefore inevitably be ad hoc."). For academic commentary on the idea-expression dichotomy, see, e.g., Amy B. Cohen, Copyright Law and the Myth of Objectivity: The Idea-Expression Dichotomy and the Inevitability of Artistic Value Judgments, 66 Ind. L.J. 175 (1990) (noting that the line between idea and expression is often a product of judge's subjective views of art); Leslie A. Kurtz, Speaking to the Ghost: Idea and Expression in Copyright, 47 U. Miami L. Rev. 1221 (1993) (seeking to identify traits of an unprotectable idea); Edward Samuels, The Idea-Expression Dichotomy in Copyright Law, 56 Tenn. L. Rev. 321 (1989) (surveying history of doctrine and noting its marginal utility). For academic commentary on the idea-expression dichotomy as applied to computer programs, see, e.g., John W.L. Ogilvie, Note, Defining Computer Program Parts Under Learned Hand's Abstractions Test in Software Copyright Infringement Cases, 91 Mich. L. Rev. 526 (1992); Peter G. Spivack, Comment, Does Form Follow Function? The Idea/Expression Dichotomy in Copyright Protection of Computer Software, 35 UCLA L. Rev. 723 (1988); Timothy S. Teter, Note, Merger and the Machines: An Analysis of the Pro-Compatibility Trend in Computer Software Copyright Cases, 45 Stan. L. Rev. 1061 (1993) (arguing that copying to achieve compatibility among software products should be allowed under the merger doctrine).

60. See 17 U.S.C. $\S 102(\mathrm{~b})$ (1988).

61. 17 U.S.C. $\S 101$ (1988). The definition was added by the Act of December 12, 1980, Pub. L. No. 96-517, 94 Stat. 3015, 3082. In enacting the 1980 amendments, Congress adopted, virtually verbatim, the recommendations of the Commission on New 
these two texts: a "set of instructions used in order to bring about a certain result" would appear, at least in lay terms, to constitute a "process," "system," or "method of operation." Since one should endeavor to construe statutes in a way that does not render them futile, ${ }^{62}$ and since we know that Congress did determine in 1980 to protect computer programs, ${ }^{63}$ the terms "process," "system," or "method of operation" must not be understood literally. As a result, some ways of achieving "a certain result" (i.e., some "behaviors") will be protected by copyright. ${ }^{64}$ What ways, and what results?

The tried-and-true (but nonetheless maddeningly elusive) "abstractions test" determines the "result" whose achievement may be protected, so long as there are a sufficient variety of alternative ways to that end. The debate, which cuts across classes of copyrighted works, focuses on the level of specificity or generality at which the "result" (or idea) is defined. ${ }^{65}$ The more specific the idea, the more likely the merger doctrine is to disqualify plaintiff's work; the more broadly defined the idea, the more likely plaintiff's rendition will survive scrutiny, and the broader the scope of plaintiff's potential protection as well. ${ }^{66}$ In effect, the merger

Technological Uses that it had appointed to study the copyrightability of computer programs.

62. See, e.g., United States v. American Trucking Ass'ns, Inc., 310 U.S. 534, 543 (1940) (declining to adopt a reading of statutory language that would lead to "absurd or futile results ... 'plainly at variance with the policy of the legislation as a whole.' " (quoting Ozawa v. United States, 260 U.S. 178, 194 (1922))); EEOC v. Commercial Office Products Co., 486 U.S. 107, 120-21 (1988) (same).

63. See Arthur R. Miller, Copyright Protection for Computer Programs, Databases and Computer-Generated Works: Is Anything New Since CONTU?, 106 Harv. L. Rev. 977, 982-85 (1993).

64. Moreover, as we have seen, some nonsoftware works of authorship are protected even though they constitute "processes" or "methods of operation" in the colloquial sense. For example, an edition of a musical score instructs the performer as to how to execute the composition, including where and with what force to place the fingers and where to breathe. See, e.g., Artur Schnabel, Editor's Preface to Beethoven: Complete Piano Sonatas, 4 (Artur Schnabel ed., 1977).

65. With respect to copyrighted works generally, see, e.g., Nash v. CBS, 899 F.2d 1537, 1540-42 (7th Cir. 1990) (television program incorporating historical analysis developed in nonfiction book held not to infringe book's expression). With respect to computer programs, for example, Whelan Assocs. v. Jaslow Dental Lab., Inc., 797 F.2d 1222 (3d Cir. 1986), cert. denied, 479 U.S. 1031 (1987), has been widely criticized for having defined the "idea" or "function" of the program too broadly. See, e.g., Dennis S. Karjala, Copyright, Computer Software, and the New Protectionism, 28 Jurimetrics J. 33, 76-80 (1987); Peter S. Menell, An Analysis of the Scope of Copyright Protection for Application Programs, 41 Stan. L. Rev. 1045, 1082-83 (1989).

66. See, e.g., Lotus Dev. Corp. v. Borland Int'l, 799 F. Supp. 203, 211 (D. Mass. 1992) (setting forth a sliding scale of characterizations of the "idea" of plaintiff's user interface).

Consider the following example: Plaintiff's work is a play in which the villain ties the heroine down to the train tracks; just as the onrushing train is about to reach the intended victim, the hero arrives and, struggling with the ropes, releases her at the last second. Today a cliche, this scene was once a theatrical innovation, and was the subject of a successful copyright infringement suit. See Daly v. Palmer, 6 F. Cas. 1132 (G.C.S.D.N.Y. 1868) (No. 3552). Suppose the defendant, having learned that literal copying of the scene 
concept has no content independent of the articulation of the idea. And the definition of the idea ultimately must be informed by public policy notions of free, and fair, competition. Whether or not the court acknowledges its inquiry, judges in copyright cases are attempting to gauge what level of protection is necessary to encourage initial creation on the one hand, while seeking to leave ample room for subsequent innovation on the other. ${ }^{67}$ Congress set a pro-protection policy when it enacted the 1980 computer software amendments, but the scope of that protection remains subject to debate. ${ }^{68}$ As the case law evolves, many of the "marketoriented" concerns that inform the Manifesto may well be incorporated into the courts' copyright analyses. ${ }^{69}$

will be reprimanded, adopts a variation, in which the villain confines the hero to a box, which she buries in a rat-filled pit; the rats will eat through the box, and then will consume the hero. As the last shards of box are about to be devoured, the heroine appears, armed with rat repellent, and frees the hero. Has defendant copied the "expression" or merely the "idea" of the scene?

1. If the "idea" is characterized as "villain ties up heroine; hero frees her from oncoming train," then plaintiff's rendition may well be deemed to "merge" with the idea. At most, the range of protectable "expression" will be limited to plaintiff's precise exposition of the scene.

2. If the "idea" is characterized as "villain attaches heroine; hero saves her from onrushing vehicle," then not only would plaintiff's precise rendition be protectable, but the scope of protection could also extend to enacting the scene with a variety of different trains and bonds. There are sufficient alternative vehicles and means of attaching the intended victim to tolerate the extension of the concept of plaintiff's "expression" to close nonliteral similarity.

3. If the "idea" is characterized as "forces of evil confine and place agent of good in imminent danger of grisly demise, but another agent of good frees the prisoner in the nick of time," then not only is plaintiff's work an "expression" of that "idea," but the scope of plaintiff's copyright might now extend to any kind of vehicle, as well as to a myriad of means of attaching the intended victim. A vast variety of extra-vehicular dangers may menace imminent grisly demises; and attaching the victim with rope, or with chains, or with other bonds are but some of many ways to imprison. In this case, the range of nonliteral "expression" broadens even more.

4. If the "idea" is characterized as "forces of evil threaten forces of good, but good prevails," then the scope of plaintiff's copyright might extend to any kind of threat of imminent grisly demise accompanied by any kind of imprisonment and last minute salvation. In that case (and on this series of examples, only in that case), defendant's version would be found to infringe. Given the breadth of the idea, there remains a large range of alternative expositions of the general theme; the sequence of imminent grisly death-imprisonment-sudden freedom is by no means the only way (or even one of few ways) to convey the triumph of good over enterprising evil.

67. Judge Easterbrook has clearly and candidly articulated the task, and its difficulties.

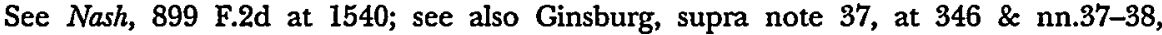
(exploring the boundaries of copyright protection with respect to ideas).

68. Compare Computer Assocs. Int'l v. Altai, Inc., 982 F.2d 693, 712 (2d Cir. 1992) (suggesting Congress was wrong to have brought computer programs within copyright law) with Lotus Dev. Corp., 799 F. Supp. at 203 (it is not for courts to second-guess Congress's choice to protect computer programs by copyright law).

69. Cf. Computer Assocs. Int'l v. Altai, Inc., 775 F. Supp. 544 (E.D.N.Y. 1991), aff'd, 982 F.2d 693 (2d Cir. 1992) (adopting analysis of court-appointed expert witness-one of the authors of the Manifesto). 


\section{CoNCLUSION}

A well-known ungrammatical adage warns against repairing that which, even if imperfect, nonetheless works reasonably well. That counsel should apply here: the evolving case law suggests that U.S. courts are successfully, if in some cases somewhat skeptically, applying copyright. analysis to computer programs. Courts, agencies, and legislatures the world over have now undertaken, through their GATT obligations, to provide copyright protection to computer programs. Also, it is not at all clear that a noncopyright "fix" to the system of software protection is available, or desirable, at least as a matter of U.S. law. Finally, the Manifesto's assessment of copyright law's ability to protect, and promote, computer program innovation is too begrudging. Copyright is more flexible and resilient than the Manifesto acknowledges: copyright law can manifest the "market-oriented" sensitivity with which the Manifesto seeks to imbue a sui generis software protection regime. 